\title{
The Effects of Adding Opioids to Anesthesia on the Recovery of Patients with Gynecological Cancer Receiving Brachytherapy
}

\author{
Brakiterapi Alan Jinekolojik Kanserli Hastalarda \\ Anestezi Uygulamasına Opioid Eklenmesinin \\ Derlenme Üzerine Etkileri
}

\begin{abstract}
Objective: The aim of this retrospective study was to investigate the effects of using propofol alone and in combination with fentanyl on postoperative analgesic consumption, duration of recovery and discharge for brachytherapy in patients with gynecological cancer.

Method: After obtaining the study approval from the local ethics committee, 67 patients who underwent brachytherapy within 5 months were included in the study. All patients received midazolam for premedication and propofol (in case of need together with fentanyl) for induction. Patients were categorised into two groups as those using (Group I, n=37) and not using opioids (Group II, n=30). The duration of the procedure, drug doses, hemodynamic data, time to recovery and discharge were obtained from records and evaluated.

Results: The duration of operation was similar in both groups. Propofol consumption was 1.865 $\mathrm{mg} \mathrm{kg}^{-1}$ in Group I and $2.03 \mathrm{mg} \mathrm{kg}^{-1}$ in Group II (p>0.05). The average fentanyl consumption in the opioid group was $1.12 \mathrm{mg} \mathrm{kg}^{-1}$ and the average age was significantly lower in this group. No difference was detected between the groups in terms of the analgesic consumption and the time to recovery and discharge.

Conclusion: Anesthetics with shorter half-life are preferred in daily interventions. This study showed that the average age of the patients who required fentanyl during anesthesia for brachytherapy was lower; and the fentanyl that is administered additionally did not lead to significant prolongation of recovery time.
\end{abstract}

Keywords: Brachytherapy, outpatient anesthesia, opioid use, analgesic consumption, recovery time

\section{öz}

Amaç: Bu çalışmada, jinekolojik kanserli hastalarda brakiterapi için günübirlik anestezi uygulamalarında tek başına propofol kullanımı ile propofole ilaveten fentanil kullanımının, anesteziden derlenme süresi, postoperatif analjezik tüketimi ve taburculuk sürelerine etkilerini retrospektif olarak araştırmayı planladık.

Yöntem: Yerel Etik Kuruldan çalışma onayı alındıktan sonra, 5 aylık sürede brakiterapi yapılan 67 hasta çalışmaya dahil edildi. Bütün hastalara premedikasyon amaçlı midazolam, indüksiyon için propofol ve gerektiğinde fentanil uygulanmıştı. Kayıtlardan ulaşılan hastalar, opioid kullanılan (Grup I, n=37) ve kullanılmayan (Grup II, $n=30$ ) olmak üzere 2 gruba ayrıldı. Işlem süreleri, kullanılan ilaç dozları, hemodinamik veriler, derlenme süreleri, taburculuk süreleri kayıtlardan ulaşılarak değerlendirildi.

Bulgular: Operasyon süresi 2 grupta benzerdi. Propofol tüketimi Grup I'de ortalama $1.865 \mathrm{mg}$ $\mathrm{kg}^{-1}$, Grup II'de $2.03 \mathrm{mg} \mathrm{kg}^{-1}$ idi (p>0.05). Ortalama fentanil tüketimi opioid grubunda $1.12 \mathrm{mcg}$ $\mathrm{kg}^{-1}$ idi ve yaş ortalaması bu grupta anlamlı olarak düşüktü. Postoperatif analjezik tüketimi, derlenme zamanı ve taburculuk zamanı bakımından 2 grup arasında fark yoktu.

Sonuç: Günübirlik girişimlerde hastanın anesteziden kısa sürede derlenmesi için yarılanma ömrü kısa anestetikler tercih edilmektedir. Çalışmamızda, brakiterapi için anestezi uygulamasında fentanil gereksinimi olan hastaların yaş ortalamasının daha düşük olduğunu ve ilave verilen fentanilin derlenme süresinde anlamlı uzamaya neden olmadığını bulduk.

Anahtar kelimeler: Brakiterapi, günübirlik anestezi, opioid kullanımı, analjezik tüketimi, derlenme zamanı

(C) Telif hakkı Anestezi ve Reanimasyon Uzmanları Derneği. Logos Tıp Yayıncılık tarafindan yayınlanmaktadır. Bu dergide yayınlanan bütün makaleler Creative Commons Atff-GayriTicari 4.0 Uluslararası Lisansı ile lisanslanmıştır.

(c) Copyright Anesthesiology and Reanimation Specialists' Society. This journal published by Logos Medical Publishing. Licenced by Creative Commons Attribution-NonCommercial 4.0 International (CC BY-NC 4.0)
Alındığı tarih: 23.05.2019

Kabul tarihi: 12.09 .2019

Yayın tarihi: 31.10 .2019

Atıf vermek için: Argun G, Gevenkiriş S, Ünver S. The effects of adding opioids to anesthesia on the recovery of patients with gynecological cancer receiving brachytherapy. JARSS 2019;27(4):272-6.

Güldeniz Argun

SBÜ. Dr A Y Ankara Onkoloji Sağlık Uygulama ve Araştırma Merkezi, Anesteziyoloji ve Reanimasyon Bölümü, Ankara - Türkiye guldargun@yahoo.com ORCID: 0000-0002-3762-3266

S. Gevenkiriş 0000-0001-8449-069X S. Ünver 0000-0002-1025-9361 SBÜ. Dr A Y Ankara Onkoloji Sağ lık Uygulama ve Araştirma Merkezi, Anesteziyoloji ve Reanimasyon Bölümü, Ankara, Türkiye 


\section{INTRODUCTION}

Brachytherapy is applied by placing a radiation source in or near the target tumor tissue in gynecological malignancies. Brachytherapy provides high-dose radiotherapy (RT) that reaches the target tissue more properly in the local treatment of cervix tumor and protects the surrounding tissues ${ }^{(1)}$. However, brachytherapy is an extremely painful procedure that includes the direct placement of sharp-tipped catheter needles to reach the tumor and the target tissue through the perineum. For this reason, patients need anesthesia during brachytherapy. These procedures are performed in a brachytherapy section in the RT unit. The room where the applicator is placed and the room where RT is applied are located in different places within the RT unit. Applicators may be permanent or disposable for several RT sessions. If the applicators are disposable, re-anesthesia is required for each applicator. If it is a permanent applicator used throughout all sessions, patient requires continuous pain treatment. For this purpose, patient-controlled analgesia (PCA) methods can be used. Repetitive applications and multiple dilator applications are the factors that affect severity of pain. Moreover, patients must be isolated and immobilized for radiotherapy following interventions, which also requires early recovery. Despite the obvious invasiveness of brachytherapy, the pain scores and treatments of patients who have gynecological cancers have not yet been determined at a sufficient level. PCA methods applied through the epidural route are among the most commonly used methods (2). Disadvantages such as lack of experienced staff, requirement for staff working for $24 \mathrm{~h}$ and the lack of monitoring may limit the use of epidural analgesia. There are variations in the need to determine the opioid or the oral analgesics and their dosages to alleviate post-implantation pain. The number of implants, parts and dilators applied for each treatment affect the need for analgesics ${ }^{(3)}$. Anesthetics with a short half-life are preferred in daily interventions for recovery of the patient in a short time. There are several anesthetic agents such as propofol, benzodiazepine, ketamine, opioid and dexmedetomidine ${ }^{(4)}$. Propofol is the most preferred agent because of its advantages such as the rapid onset of action, safe sedation and rapid arousal ${ }^{(5,6)}$. On the other hand, it also has several adverse effects such as the obstruc- tion of the airway and depression in the respiratory and cardiac systems, which may develop depending on the dose ${ }^{(7-9)}$.

In the present study, we planned to examine retrospectively the effects of using propofol alone and in combination with fentanyl on the duration of recovery from anesthesia, postoperative analgesic consumption and time to discharge of patients with cervical cancer in daily anesthesia practice for brachytherapy.

\section{MATERIAL and METHOD}

A total of 67 patients who had received brachytherapy between January 1 and May 31, 2018, were retrospectively included in this study after obtaining the local ethics committee approval (13/02/201829-5) and the informed consent from each patient. The data of 48 patients with cervix cancer and those of 19 patients with endometrial cancer were obtained from hospital records. Each patient was included in the study once, on the first day of the brachytherapy session. Based on data obtained from the records, all patients were administered 1-2 mg midazolam intravenously for premedication. Some patients were administered $1-3 \mathrm{mg} \mathrm{kg}^{-1}$ IV propofol alone, or 1-3 mg kg-1 IV propofol and 1-2 $\mathrm{\mu g} \mathrm{kg}^{-1} \mathrm{IV}$ fentanyl combination for induction. Anesthesia was maintained with spontaneous ventilation and oxygen support. Any finding of hypertension and tachycardia in the patients suggested that the depth of anesthesia was not sufficient. Fentanyl was added as usual in our clinic in cases where the heart rate and blood pressure of the patients were $20 \%$ above the baseline values. An anti-inflammatory analgesic (tenoxicam) was administered to all patients intraoperatively for postoperative analgesia. After recovery, an additional dose of the anti-inflammatory drug was administered to the patients who reported pain. Patients whose modified Aldrete recovery scores were 10 were sent to the RT department from the intervention room. The recovery period was defined as the duration between the termination of the general anesthesia that was applied during the applicator placement and the time to start RT. The patients were left alone during the RT application for approximately $5 \mathrm{~min}$. During the RT application, the patients were unprotected and could not be monito- 
red by a monitor. After the RT process, the applicator was removed and the patients were discharged. The data of the patients who were administered only propofol or fentanyl in addition to propofol for general anesthesia were retrieved from the patient records. According to the data, the patients who had received fentanyl in addition to propofol were categorised as Group I ( $n=37$, opioid group), and those who had received propofol alone were included in Group II ( $n=30$, non-opioid group). Details regarding the drug doses and the recovery periods, whether the patients faced any problems during the period when they were left alone, postoperative requirement for anti-inflammatory medication and discharge times were collected from the medical records of the patients.

The Kolmogorov-Smirnov test was applied to determine whether the groups fit to normal distribution. The Student's t-test was used to determine whether there were any differences between the demographic data and the analgesic methods. The chi-square test (Fisher's exact test) was used to determine whether there were any differences between the two groups in terms of drug doses, hemodynamic data, times to recovery and discharge. Level of statistical significance was accepted at $p<0.05$.

\section{RESULTS}

Table I shows the demographic characteristics of the two patient groups. The impact of age factor was less significant in the opioid group (Group I/ Group II; 40.64/54 years, $p<0.05$ ) (Table I). There were no differences between the groups in terms of body weight and duration of anesthesia. The mean duration of anesthesia was $37 \pm 1.4 \mathrm{~min}$ for Group I and 35 \pm 1.6 min for Group II, without any statistically significant differences between the two groups ( $p>0.05$, Table I). Patients in both groups were administered midazolam for premedication,

Table I. Demographic characteristics of the groups (mean \pm standart deviation)

\begin{tabular}{lccc}
\hline Groups & $\begin{array}{c}\text { Opioid group } \\
(\mathbf{n}=\mathbf{3 7})\end{array}$ & $\begin{array}{c}\text { Non-opioid } \\
\text { group }(\mathbf{n}=\mathbf{3 0})\end{array}$ & $\mathbf{p}$ \\
\hline Ages (years) & $40.64 \pm 1.51$ & $58.06 \pm 1.86$ & 0.004 \\
Weight (kilogram) & $73.61 \pm 9.50$ & $72.10 \pm 9.82$ & 0.607 \\
ASA II/III & $24 / 13$ & $20 / 10$ & 0.860 \\
Anesthesia Duration (minute) & $37.06 \pm 1.45$ & $35.20 \pm 1.68$ & 0.640 \\
\hline
\end{tabular}

and there was no difference between the two groups in terms of dose of midazolam given (Group I/ Group II: 1.46/1.53 mg). The average propofol consumption was $2.03 \mathrm{mg} \mathrm{kg}^{-1}$ in the non-opiod group and $1.865 \mathrm{mg} \mathrm{kg}^{-1}$ in the opioid group, without any statistically significant difference between groups $(p>0.05)$. Fentanyl was added to patients with hypertension or tachycardia. In Group I, there were 4 patients with hypertension and 5 patients with tachycardia. The average fentanyl consumption was $1.12 \mathrm{mcg} \mathrm{kg}^{-1}$ in the opioid group during the entire duration of anesthesia. The average recovery time was $10.06 \mathrm{~min}$ in the opioid group and $9.0 \mathrm{~min}$ in the non-opioid group, without any significant intergroup difference. There was also no significant difference between the two groups in terms of the postoperative dose of additional analgesics (tenoxicam, Group I/Group II: $23.7 / 26.7 \mathrm{mg}$ ). The time to discharge after the intervention was similar in both patient groups (Group I/Group II: 93.5/92.7 min) (Table II).

Table II. The amounts of the drugs used, recovery times, additional analgesic requirement, discharge times (mean \pm standarddeviation)

\begin{tabular}{lccc}
\hline Groups & $\begin{array}{c}\text { Opioid group } \\
(\mathbf{n}=\mathbf{3 7})\end{array}$ & $\begin{array}{c}\text { Non-opioid } \\
\text { group (n=30) }\end{array}$ & p \\
\hline Midazolam (mg) & $1.46 \pm 0.02$ & $1.53 \pm 0.08$ & 0.108 \\
Propofol (mg kg-1) & $1.86 \pm 0.15$ & $2.03 \pm 0.30$ & 0.146 \\
Fentanyl $\left(\mu \mathrm{gg}^{-1}\right)$ & $1.12 \pm 0.07$ & 0 & 0.150 \\
Recovery (min) & $10.06 \pm 1.63$ & $9.00 \pm 1.09$ & 0.640 \\
Postoperative analgesics & $23.70 \pm 2.32$ & $26.70 \pm 2.05$ & 0.082 \\
(Tenoxicam) (mg) & & & \\
Adverse effects (nausea, & $0,0 \%$ & $0,0 \%$ & \\
vomiting, drowsiness) (n,\%) & & & \\
Hypertension (n,\%) & $4,10.81 \%$ & $0,0 \%$ & $0.033^{*}$ \\
Tachycardia (n,\%) & $5,13.51 \%$ & $0.0 \%$ & $0.045^{*}$ \\
Discharge (min) & $93.50 \pm 8.20$ & $92.70 \pm 8.95$ & 0.205 \\
& & & \\
\hline
\end{tabular}

\section{DISCUSSION}

This study demonstrated that the mean age of the patients who required fentanyl in addition to propofol was lower during the outpatient anesthesia that we applied for brachytherapy and that fentanyl that was added did not lead to significant prolongation in recovery times. Although time to recovery was longer in the group in which fentanyl was added than in the group to which fentanyl was not added with a statistically significant difference between groups. Using separate applicators for each brachytherapy 
session had eliminated the need for continuous pain treatment during brachytherapy. In other words, the use of opioids, and only short-term superficial anesthesia was required during the procedure. It was also observed that low-dose opioid use did not have a negative effect in terms of recovery and adverse effects in daily interventions.

A previous study that was conducted to assess daily anesthesia application for gastrointestinal endoscopy compared the use of propofol alone with propofol + midazolam + fentanyl anesthesia ${ }^{(10)}$. It was found that lower doses of propofol were administered in the combined drug group. Besides, hypotension was less frequently detected in this group, and recovery was faster. There were no differences between the two groups in terms of patient satisfaction and postoperative adverse effects. Drowsiness was more frequent in the combined drug group. It was emphasized that propofol was a sufficiently effective and reliable anesthetic agent that can be used alone in daily anesthesia interventions.

Mendez et al. ${ }^{(11)}$ examined the pain scores and opioid consumption until the removal of the applicator in the postoperative period and in daily anesthesia applications for brachytherapy. They applied general anesthesia to all patients during the insertion of the applicator. General anesthesia was induced using intravenous anesthetic agents (propofol) or inhalation anesthetics agents and opioids. The applicator was not removed for 2 days until the completion of the brachytherapy application, and during this period, pain treatment was ensured by intravenous PCA (IV-PCA) or using oral opioids. Opioid consumption was found to be higher in the IV-PCA group than in the opioid group (69.8/32.1 mg morphine). Opioid consumption was also found to be higher in younger patients and in those who had previously used opioids. The size of the dilator used during the process and the location and size of the tumor did not affect opioid consumption. Since the applicator remains in its place during the treatment, patients will have pain and require analgesics. In our study, the applicator was re-inserted in each brachytherapy application and was removed immediately after the treatment. There was no need for prolonged pain treatment, non-steroidal anti-inflammatory drugs were adequate for the treatment of pain and the patients were discharged immediately after the procedure.

Latremoliere et al. ${ }^{(12)}$ reported the use of an average of $55 \mathrm{mg}$ oral morphine per day during the first insertion of the applicator. They demonstrated that this dose had to be increased at a rate of $50 \%$ in the second insertion. They explained this finding through the sensitization phenomenon that appeared in the presence of repetitive pain stimuli strengthened by the nociceptive system. It is possible that the inflammatory process that occurs during the first insertion of the applicator increases the dose of morphine consumption.

In a previous study in which brachytherapy was applied to 25 patients under general and spinal anesthesia, it was demonstrated that spinal anesthesia reduced the total opioid use and the patients could be transferred to the department where brachytherapy was applied, and this approach did not prolong the procedural time ${ }^{(13)}$. The necessity of follow-up for these patients and the inability of being discharged rapidly from the hospital may result in limitations in the regional anesthesia methods. In the present study, the time to recovery was observed to be shorter with general anesthesia methods in daily interventions, and the patients were discharged earlier.

A limitation of our study was that it had a retrospective design; therefore, there was no similarity in age distribution between the groups.

\section{CONCLUSION}

This study demonstrated that comparatively younger patients required fentanyl in addition to propofol during anesthesia administered for brachytherapy and that the additional fentanyl did not lead to any significant prolongation in the time to recovery. We believe that further studies are needed to evaluate the effect of opioids on recovery in outpatient anesthesia applications because the patients who received additional fentanyl were statistically significantly younger. 
Etik Kurul Onayı: T.C. Sağlık Bakanlığı II Sağlık Müdürlüğü Dr. Abdurrahman Yurtaslan Ankara Onkoloji SağIık Uygulama ve Araştırma Merkezi Etik Kurul onayı alınmıştır (29.05.2019/291).

Çıkar Çatışması: Yoktur

Finansal Destek: Yoktur

Hasta Onamı: Retrospektif çalışma

Ethics Committee Approval: T.C. Ministry of Health Provincial Health Directorate Abdurrahman Yurtaslan Ankara Oncology Health Application and Research Center Ethics Committee approval was obtained (29.05.2019/291).

Conflict of Interest: None

Funding: None

Informed Consent: Retrospective study

\section{REFERENCES}

1. Bhanabhai H, Samant REC, Grenier L, Lowry S. Pain assessment during conscious sedation for cervical cancer high-dose-rate brachytherapy. Curr Onco. 2013;20:307-10. https://doi.org/10.3747/co.20.1404

2. Roessler B, Six LM, Gustorff B. Anaesthesia for brachytherapy. Curr Opin Anaesthesiol. 2008;21:514-8. https://doi.org/10.1097/ACO.0b013e32830413cb

3. Rollison B, Strang P. Pain, nausea and anxiety during intra-uterine brachytherapy of cervical carcinomas. Support Care Cancer. 1995;3:205-7. https://doi.org/10.1007/BF00368893

4. Triantafillidis JK, Merikas E, Nikolakis D, Papalois AE. Sedation in gastrointestinal endoscopy: current issues. World J Gastroenterol. 2013;19:463-81. https://doi.org/10.3748/wjg.v19.i4.463

5. Robertson DJ, Jacobs DP, Mackenzie TA, Oringer JA, Rothstein RI. Clinical trial: a randomized, study compa- ring meperidine (pethidine) and fentanyl in adult gastrointestinal endoscopy. Aliment Pharmacol There. 2009;29:817-23. https://doi.org/10.1111/j.1365-2036.2009.03943.x

6. Wang D, Chen C, Chen J, et al. The use of propofol as a sedative agent in gastrointestinal endoscopy: a metaanalysis. PLoS One. 2013;8:53311. https://doi.org/10.1371/journal.pone.0053311

7. Gras S, Servin F, Bedairia E, et al. The effect of preoperative heart rate and anxiety on the propofol dose required for loss of consciousness. Anesth Analg. 2010;110:89-93. https://doi.org/10.1213/ANE.0b013e3181c5bd11

8. Tsai CJ, Chu KS, Chen TI, Lu DV, Wang HM, Lu IC. A comparison of the effectiveness of dexmedetomidine versus propofol target-controlled infusion for sedation during fibreoptic nasotracheal intubation. Anaesthesia. 2010;65:254-9. https://doi.org/10.1111/j.1365-2044.2009.06226.x

9. Lam F, Liao CC, Lee YJ, Wang W, Kuo CJ, Lin CS. Different dosing regimens for propofol induction in obese patients. Acta Anaesthesiol Taiwan. 2013;51:53-7. https://doi.org/10.1016/j.aat.2013.06.009

10. Hsu CD, Huang JM, Chuang YP, et al. Propofol targetcontrolled infusion for sedated gastrointestinal endoscopy: A comparisonof propofol alone versus Propofole fentanyle midazolam. Kaohsiung J Med Sci. 2015;31:1-5. https://doi.org/10.1016/j.kjms.2015.09.004

11. Mendez LC, Choi S, D'Alimonte L, Barnes E, Barbera L, Leung $\mathrm{E}$. Opioid consumption and pain in gynecological cancer patients treated with interstitial brachytherapy. Brachytheraphy. 2017;16:870-6. https://doi.org/10.1016/j.brachy.2017.04.246

12. Latremoliere $A$, Woolf $C$. Central sensitization: a generator of pain hypersensitivity by central neural plasticity. J Pain. 2009;10:895-926. https://doi.org/10.1016/j.jpain.2009.06.012

13. Frankart AJ, Meier T, Minges TL, Kharofa J. Comparison of spinal and general anesthesia approaches for MRIguided brachytherapy for cervical cancer. Brachytherapy. 2018;17:761-7. https://doi.org/10.1016/j.brachy.2018.05.002 